\title{
Negotiations and Conflict in the Implementation of a Waste Pickers' Cooperative: A Sociology of Translation Approach
}

\author{
Priscila Soraia da Conceição Ribeiro ${ }^{1, *}$, Emília Wanda Rutkowski ${ }^{2}$ and Sonaly Rezende ${ }^{3}$ (D) \\ 1 Academic Department of Engineering, Federal Technological University of Paraná (UTFPR), \\ Linha Santa Bárbara, Francisco Beltrão 85601-970, Brazil \\ 2 FLUXUS, Teachlearning Laboratory on Urban Morphology and Socio-Environmental Sustainability, \\ Department of Infrastructure and Environment, School of Civil Engineering, Architecture and Urban Studies, \\ UNICAMP-University of Campinas, Campinas 13083-889, Brazil; emilia@fec.unicamp.br \\ 3 Department of Sanitary and Environmental Engineering, Federal University of Minas Gerais, \\ Av. Antônio Carlos, 6627, Belo Horizonte 31270-901, Brazil; srezende@desa.ufmg.br \\ * Correspondence: priscilas@utfpr.edu.br; Tel.: +55-(19)-9-2002-2373
}

Citation: Conceição Ribeiro, P.S.d.;

Rutkowski, E.W.; Rezende, S.

Negotiations and Conflict in the Implementation of a Waste Pickers Cooperative: A Sociology of Translation Approach. Sustainability 2021, 13, 12889. https://doi.org/ $10.3390 /$ su132212889

Academic Editor: Silvia Fiore

Received: 17 October 2021

Accepted: 16 November 2021

Published: 21 November 2021

Publisher's Note: MDPI stays neutral with regard to jurisdictional claims in published maps and institutional affiliations.

Copyright: (C) 2021 by the authors Licensee MDPI, Basel, Switzerland. This article is an open access article distributed under the terms and conditions of the Creative Commons Attribution (CC BY) license (https:// creativecommons.org/licenses/by/ $4.0 /)$

\begin{abstract}
The complexity of converting political options into socially, economically, and environmentally acceptable strategies places collectors of recyclable material and the challenges they experience on the agendas of research in science, technology, and society. This article aims to investigate the negotiations and conflicts that permeated the implementation of a waste pickers' cooperative and its integration into the municipal solid waste management system. Considering the complexity of the theme, the methodological approach adopted was grounded theory. This method encourages the expansion of knowledge in an area through the connection of theoretical concepts and significant aspects of the actors' experiences. The techniques applied for data collection included semi-structured interviews, participant observation, document analysis, and informal interviews. The results are based on narratives analyzed from concepts derived from the Sociology of Translation. It was possible to observe the efforts undertaken by multiple actors, sometimes in the construction and other times in the destabilization of a support network for the establishment of a cooperative. The network suffered dissidents and was destabilized by the habits of the original network and by unexpected events, which made the results achieved opposite to desired ones. In the end, the network was not stabilized, and municipal solid waste management was unchanged.
\end{abstract}

Keywords: integrated solid waste management; grounded theory; human and non-human actors; actor-network theory

\section{Introduction}

Solid waste management has always dealt with two extremes: non-generation and pollution resulting from generation [1]. In this contradictory space, in which the best and worst scenarios are presented, the authors recommend that practical solutions align with the policy options. For this, it is necessary to convert political alternatives into socially acceptable and economically viable options. In other words, to promote environmentally sustainable strategies to reduce the impacts associated with waste, transforming them into useful resources through local socioeconomic and cultural precepts. Waste recovery offers opportunities for reducing pollution, job creation, and poverty alleviation [1].

In the global South, the recovery of waste through recycling is supported by an extensive informal sector responsible for carrying out the collection and separation of recyclable materials [2-4]. Collecting is an economic activity that makes up the social fabric of cities, making waste pickers an intrinsic part of the urban landscape [5].

These workers are included in the recycling chain in a perverse, precarious, and marginal way [6]. After collecting and sorting recyclables, workers sell materials at low prices to intermediaries or informal traders, who resell them to recycling companies [7-9]. 
The value added by the cooperative up to the last buyer reaches $85 \%$, and for some materials, exceeds $100 \%$ [9].

In addition to producing goods by recovering waste, collectors are involved in the management of this material, a prerogative of local governments. This action takes place in the context of conformity with precarious working conditions by legally responsible entities and non-governmental organizations [10].

However, despite the importance of the work carried out by collectors, these actors continue to struggle to be fully recognized as service providers and continue to be associated with conditions of exploitation, child labor, unhealthy conditions, and social exclusion [7,11-14]. Invisible and discriminated against for being low-income and due to the tasks they perform, the collectors also work as environmental agents and fill a gap left by the State and the formal economy $[15,16]$.

This scenario justifies theorizing the decisive factors for the recognition of collectors in waste management. In this sense, several researchers have dedicated themselves to understanding the performance of the informal sector, highlighting the central role, albeit neglected, that waste pickers play $[2-4,7,10-14,17-19]$. These studies highlight the importance of the political and socioeconomic organization of waste pickers, emphasizing the social relations between them and with local authorities as decisive factors for the success of the recognition of these actors [20].

This article contributes to research in science, technology, and society relating to the challenges associated with the implementation and continuity of a waste pickers cooperative as a service provider in municipal solid waste management. The originality of this paper is based on the application of the grounded theory (constant comparison and theoretical sampling). This method encourages the expansion of knowledge in an area through the connection of theoretical concepts and significant aspects of the actors' experiences in the implementation of a waste picker cooperative.

The city of Porto Feliz was used as a case study. This work describes the local situation and its regional importance and contributes to the discussion of the architecture of the socio-technical network that supports cooperative waste pickers. The configurations that induce relative stability and amplify the potential for inclusion of the informal sector in waste management are discussed.

This paper is organized into three main sections that articulate the agents' narratives in the construction and maintenance efforts of the cooperative. The first contains the narrative of the construction of the support network for the cooperative of recyclable material collectors in Porto Feliz; the second section illustrates human and non-human efforts to destabilize the emerging network; and, finally, the third section discusses the case study from the contributions and analytical tools of Sociology of Translation.

\section{Materials and Methods}

Waste pickers are the main object of this article and their world was approached from their own narratives and from the perspectives of local actors involved with recycling. The complexity of accessing this world resulted in the use of grounded theory (GT) as an investigation method. It is an abductive process that results in the generation of formal and substantive theory $[21,22]$.

GT is based on two axes: constant comparison and theoretical sampling [21,22]. Constant comparison requires simultaneous collection and analysis in a circular and interconnected process. The collection methods were adapted according to existing reality $[21,23,24]$. The theoretical sampling consisted of controlling data collection using a theory that emerges from previously obtained information. The first sampling was the researcher's choice, who continues to seek new data to achieve the expected variation in the observed dimensions [24-28]. The total number of respondents was determined by the principle of theoretical saturation, that is, when the information obtained is repeated, without additions or modifications [24,26,27,29]. 
The case study option was supported by an empirical investigation that included a comprehensive method, with data collection and analysis for the municipality of Porto Feliz. The municipality, which is located in the state of São Paulo, has an estimated population of 51,907 inhabitants in 2021 [30], and an HDI of 0.758 [31]. In 2010, 97\% of households (urban and rural) located in agglomerations had access to a door-to-door collection service, and $57 \%$ of rural households dispersed in the municipality [32].

Information was collected between November 2019 and August 2020. Data collection techniques included semi-structured interviews with 26 key actors (cooperative and selfemployed waste pickers, municipal public managers, and members of organized civil society), participant observation, and informal interviews.

In the presentation of the research results, narratives were used that contributed to giving consistency to the empirical data, demonstrating their coherence, allowing for the creation of a new understanding of the phenomena under study [33,34]. To respect the ethical issues of maintaining the confidentiality of the participants, the actors were presented more comprehensively (e.g., like an employee of the city hall, without identifying the position occupied). This strategy is in line with the methodological approach adopted, as it seeks potential ways to analyze a specific issue, which will lead to generalization. The approach does not seek to assess the identity of those involved, but rather the way they place themselves in the process under analysis.

The first topic of this article covers narratives that describe attempts to build and stabilize the cooperation of collectors integrated into municipal solid waste management. The second topic encompasses narratives of actions taken to destabilize the process.

\section{Results}

\subsection{Actions to Create a Municipal Waste Recycling Network through a Waste Picker Cooperative}

The first record of a movement to build a cooperative on the Porto Feliz dates from 2008. A meeting promoted by the municipal government and the Brazilian Service for Support to Micro and Small Enterprises had as its agenda the implementation of a cooperative aimed at recyclable collectors [35]. In the same year, the position of Mayor of Porto Feliz was occupied by Claudio Maffei from the Worker's Party. At the time, Maffei had just been re-elected in the first round of the municipal election, with $69.5 \%$ of the valid votes [36].

After 17 months, more than 20 meetings were organized for the waste picker cooperative, named Monções, composed of 18 founding members. The decision was made at the extraordinary meeting held in March 2010, promoted by the Sustainable Development Commission, linked to the Social Development Municipal Board of Directors [37].

The Statute of the Cooperative was approved in assembly, as was elected by its treasurer and its president. The first position was occupied by the Social Development Municipal Director [37,38]. The presidency was assigned to an environmental engineering student, later hired as an intern at the Environment Municipal Board of Directors, in 2010, according to his report:

One day, I opened the newspaper and saw that they were forming a recycling cooperative in the city ( ... ) I was willing to help, they needed someone to take care of the spreadsheets, to do the line of reasoning, and ... I wanted the final term paper. Then, I joined as an intern at the time of the prefecture.

The supervising professor of internship and undergraduate work had no direct participation in his activities.

In interviews conducted with employees of the Departments of Environment and Public Works and Urbanism, who are in charge of solid waste management in the municipality, they showed total ignorance of the processes that culminated in the formation of the cooperative. The process involved people in situations of social vulnerability assisted by the Social Development Municipal Board of Directors appointed by the Reference Center for Social Assistance [37,39]. These people, mostly women who did not work as waste pickers, were looking for a source of income, as reported by a citizen who accompanied the cooperative's work: 
The cooperative project was born through social assistance, not linked to a solid waste thematic. What was our commitment? To make the cooperative members have a decent job, a minimum wage, and try to achieve the minimum. This is a social issue under the control of the Reference Center for Social Assistance (... ).

A publication in digital media with a regional focus, dated March 2010, before the formalization of the Cooperative, evidenced the movement of the Social Development Municipal Board of Directors publicizing the implementation of the cooperative. The same text promoted population awareness about the importance of separating recyclable materials. Residents of neighborhoods that would be covered by the selective collection and were interested in sending their recyclable waste to the cooperative would need to register to have access to the collection service every Monday when the municipal truck passed through the city [39].

In the second month of operation, the cooperative acquired a press through a loan agreement between the municipal government and the company Laerte Reciclagem de Itu. The cooperative headquarters started to function as a recyclable volunteer delivery point in a rented local by the municipal administration in the central region of the headquarters district [40].

These efforts yielded good results. In the first month of operation, the cooperative added 12 people in the line of work, recovering about $2000 \mathrm{~kg}$ of paper, $1000 \mathrm{~kg}$ of scrap, $800 \mathrm{~kg}$ of glass, and $62 \mathrm{~kg}$ of aluminum [40]. After one year of operation, the cooperative segregated more than 100 tons of recyclables [41].

Regarding the Cooperative's disclosure, one of the former members reported:

In the beginning, it was all word-of-mouth. We were informed: "There is the Cooperative, we want to recycle material", [they asked] "What kind of material?" (...), and the staff adhered perfectly. Many praised.

We wrote down the house number and street name (... ). It was all a matter of us to publicize, right? We said to the people from whom we collected recyclables:

"Talk to your neighbor. If he has material, [ask] him to keep it, which we pass [collecting]."

The president of the cooperative graduated from his university studies in 2010 and his position as an intern was concluded. The vacant position was occupied by a citizen who was very engaged in socio-environmental municipality issues. While participating in the cooperative, the citizen in question was retired. He took part in several municipal councils and was present from the first meetings to organize the cooperative.

The municipal government recognized the importance of a technical position to support cooperative members when the intern left the cooperative. Thus, a new intern was hired, whose formation in business administration positively influenced the creation of a business plan for cooperative expansion. In the same way, the university and the supervisor professor do not have direct relationships with the cooperative.

In April 2011, the "Recycling with Citizenship" Project was implemented with the support of the Social Development Board. This initiative extended selective collection throughout the entire urban area of the municipality. At the time, the cooperative had recovered an estimated 15 tonnes of recyclable materials per month, a volume that was expected to double in 1 year [42].

In February 2012, the "Eco-Oil" Program was initiated for the collection of vegetable oil in selective collection areas and in points of voluntary delivery in the Cooperative's headquarters and at all health centers and References Centers for Social Assistance [43]. At this time, the cooperative had 14 active members and received support from the Social Development Municipal Board of Directors.

Between 2011 and 2012, the cooperative also joined the Collective Recycling Program developed by the Coca-Cola Brazil Institute and received support from LANXESS, a German company operating in the chemical and polymer sectors, which has an installed unit in Porto Feliz. 


\subsection{Counter Actions That Destabilized the Emerging Network}

The political scenario in Porto Feliz changed in 2013, the year of the Mayoral election, which resulted in the election of Levi Rodrigues Vieira from the Social Democratic Party. The Secretariat of the Environment became the link between cooperative members and the municipal public power and was very different from the previous administration. The new managers believed that the presence of a technician in the cooperative was not necessary. An employee who occupied a commissioned position in the Secretariat of the Environment, among several other functions, was enough to meet the specific demands of the cooperative.

Another important modification in the first year of the new administration of the cooperative was represented by a change in address to a neighborhood far from the city's commercial center, at the site of a large generator of recyclables [44]. The shed did not have the minimum infrastructure such as restrooms and areas reserved for making meals and the rest for cooperative members. At the time, a city councilor reported the following:

(... ) a structure of cooperative members far below dignity, with no men's restroom, only one bathroom. (... ) The structure was inadequate.

The year 2013 was also marked by a strong storm in the region of Porto Feliz. The event caused three deaths and many material losses resulting from landslides [45]. This natural phenomenon also greatly damaged the cooperative's newly inaugurated headquarters, marking its trajectory: the shed lost its cover, the walls collapsed, and documents and equipment were damaged.

After the storm, the cooperative did not have a suitable structure to continue with its activities. As a result, the cooperative remained paralyzed until a local businessman assumed the expenses related to the repair of and improvement of the shed, including the addition of a dressing room and a dining room. At that time, 19 cooperative members obtained their income from the sale of segregated material. None of the interviewees knew how to explain the reasons for this donation, and it was not possible to reach or interview this businessman.

The cooperative returned to work and from the knowledge accumulated by its members, new collaborations and projects were started or continued. At this point, cooperative members realized the need to maintain partnerships and the importance of their role as awareness-raising agents in the community.

In October 2013, the Cooperative started the "Recicla Porto" project, with support from Lanxess, the Coca-Cola Brasil Institute, Carobi Indústria e Comércio de Produtos Químicos LTDA, the Water and Sewage Service of Porto Feliz, and City Hall. The project involved a new registry of households covered by waste collection. Citizens competed for gifts if they provided a certain amount of material for selective collection. The action was treated as an instrument for environmental awareness [46].

In the same year, in September, October, and November, the Municipal Ecological Gymkhana, an event was organized by Secretariats of Social and Sustainable Development and Education, Culture and Sports with support from the cooperative and partner companies. The event consisted of a competition to collect PET bottles and aluminum cans in all schools from the municipal network of Porto Feliz. Schools that gathered the highest volumes of material won prizes, including bicycles and laptops. The weekly collection of waste stored in schools was taken on by the Cooperative, which received the collected materials [46].

Despite a decrease in the support given to the cooperative by the municipal government, in December 2013, Municipal Law No. 5226/2013 entered into force, which stated that the cooperative was to be referred to as a public utility [47]. The first municipal regulation referring to the entity was established, and expenses with rent, water, and electricity for the shed granted to the cooperative were included in the budget planning of the municipality. Despite this, the cooperative was not officially contracted.

During this period, recyclable waste collection activity began to be strongly affected by the absence of a vehicle solely dedicated to this purpose. Until 2013, City Hall had already 
destined a used truck, in a state of deterioration, for use in the collection of recyclables by the cooperative. However, the vehicle began to require constant repairs, making it difficult to comply with the work schedule established by cooperative members.

According to one of the cooperative members at the time:

They provided support, but not officially, right? ( . . ) when the truck broke down, we had to fix it, and it was not the support that the cooperative needed. Support was lacking for the cooperative to operate adequately. Many citizens of Porto Feliz would not be unemployed today. We had support, but it was not the support that the cooperative needed. I think if they [public managers] wanted to, they could help a lot more.

As an alternative, the cooperative acquired a vehicle, which ultimately generated two further inconveniences: it had limited capacity and began to overload the entity's budget. In view of the pressures exerted by the cooperative's leaders on representatives of the Municipal Legislative Power, in 2014 a parliamentary amendment signed by then State Deputy Chico Sardelli, from the Green Party, was proposed for the purchase of a truck for sorted waste collection. However, the truck was in the possession of the City Hall, and on several occasions, it was diverted from its primary function. The truck was destined for other uses, also understood as priority, and this created new and intense clashes between cooperative members and the municipal government.

One of the city councilors stated at the time:

My conquest was followed by a buck of cold water because they [waste pickers] had an old truck. I thought to myself "an old truck, with a new truck, would double collection." The new truck arrives at the cooperative, and the past administration removes the old truck. So it goes on ...

(... ) as it was an amendment that came to the City Hall, the City Legal Department understood that this truck could not be donated to the cooperative. It remained owned by the City Hall for use by the cooperative. It was supposed to be exclusive, but it was not. If there was pruning of a tree branch, the sorted waste collection had to be stopped.

The interviewed cooperative members also reported their relationships with the truck team that worked in sorted waste collection. According to reports, when they were permanent City Hall employees, the coexistence was conflicting. However, when they were proactive outsourced employees, cooperative members did not feel excluded.

In the period between 2014 and 2017, little information was obtained. In a report about his visit to the Cooperative in 2016, an NGO Porto Ambiental member reported:

(... ) You see a lack of management. There was a pile of garbage [in the shed]. It was garbage, I am not talking about recyclable material, which [cooperative members] discarded at the time of separation, and was being created as a gigantic mountain of garbage. There was no conversation with the City Hall to remove it ... This delay generated a great accumulation of garbage. When City Hall realized ... there was also recyclable material!

This is a lack of management. ( . . ) I said: you need to get this material out of here, it's unhealthy to work in a place like this. The more you accumulate, the more difficult it will be. The logical things that the manager would do and that they had difficulty with. You have to talk to City Hall, and that's the priority!

The lack of information during this period is attributed to the City Hall, which does not have records of the situation in the cooperative. Moreover, those cooperative members who played a leadership role during this period were reluctant to talk about what had happened.

Some of the members of the cooperative revealed suppositions and rumors of theft and misappropriation of funds by waste pickers who assumed leadership positions. Such information may or may not be representative of the facts, but this situation ultimately 
culminated in the Cooperative's decline. The narrative of these actors reveals: (i) that the municipal government does not assume financial compensation for the work carried out by the cooperative, (ii) a lack of cohesion among cooperative members, and (iii) low organizational capacity. Given this situation, in addition to the drop in monthly income, there was evasion of cooperative members.

One of the cooperative members reported:

(... ) The money we earned was very little. Sometimes we worked overtime on Saturdays ... I did everything: I got on the truck, collected recycled material, worked a lot, and earned so little.

I used to teach the beginners. The group started to work, and it looked like they were going to earn well. However, at the end of the month, there was little money. They did not continue and did not work for a month. It was difficult to teach beginners, and almost no one was left. Sometimes, I went out on the street and had to go back and recycle.

In January 2017, at the beginning of the first year of the administration of Mayor Cássio Habice Prado, from the Brazilian Labour Party, the Municipal Government broke all ties with the Cooperative. Managers alleged irregularities in the shed and interdicted them [48].

A City Hall official who worked in the management reported:

In 2017, any contact between the City Hall and the Cooperative was terminated (... ) the rent and the partnership of this cooperative with the City Hall was suspended. The City Hall no longer paid rent, water, and electricity ( ... ) and the cooperative ceased operations.

One of the former cooperative members regretted the closure of the Cooperative:

This came out to become nothing. I am sorry because it was a place where a lot of women work ... money was little, but there was some money.

I would like the next Mayor to do something in the recycling sector. This is very good for the population and generates jobs. There are women aged 60 and 70 years who are good at this work-better than many younger women-but now they have nowhere to work.

The cleaning and structural renovation required to return the shed to its owner was paid for by City Hall. This outcome generated a series of clashes between cooperative members and the municipal government. Finally, with the loss of its headquarters, all of the cooperative's equipment and documentation (presses, sorting conveyor, files, and computers) were removed and stored in a municipal warehouse, and sorted waste collection in the municipality of Porto Feliz was interrupted.

\section{Discussion}

As recommended by grounded theory (GT), immersion in the field must follow without theoretical presuppositions. In contrast, the theory must be coherent with the reality under study, emerging from the data $[21,29,49]$. In this sense, the narratives helped to understand how the history of the Cooperativa de Coleta Seletiva Monções de Porto Feliz took place from the first meetings in 2008, which culminated in its creation, until its closure in 2017.

From the data analysis, it was observed that the conceptual repertoire of the Sociology of Translation, also called actor-network theory (ANT), would make it possible to describe the interactions between human and non-human actors-actants-that surrounded all decision-making activities related to the cooperative. Thus, the main aim of this section is to present part of the repertoire of ANT conceptual tools used to understand the case study under analysis.

ANT seeks to understand how the collective construction of facts takes place [50]. In this scenario, the use of the ANT begins with the identification of actors that constitute a 
heterogeneous (or hybrid) sociotechnical network. It seeks to characterize the way these actors are configured (in interaction), which provides explanations for the success or failure of the durability (stability) of this network [51].

ANT allows for the analysis of waste management from the perspective of the emergence and competition of different networks that support specific results $[34,52,53]$. It is characterized by a complex interaction between the specific materialities of waste and sociocultural and political changes [54]. This scope is particularly interesting for the comprehension of the conflicts that permeate solid waste management by deviating from the power of a specific actor, either being an institution, a local community, or a social movement. Such power is transferred to the construction of networks that allow a certain result to be achieved or not [55].

It is important to note that networks need to be recognized as hybrid entities, that is, composed of humans and non-humans in a symmetrical relationship [56]. Symmetry favors the use of ANT in studies on solid waste management, considering that, while humans build non-human entities, material objects are also active in the configuration of human and non-human bodies and can change the course of action [20,53].

ANT stands out for casting doubt on the usefulness of the dichotomy between social and material world; this method challenges anthropocentrism by showing that contemporary political disputes involve the management or regulation of the non-human, generating intersections between the political, scientific, technical, and ethical, and suggests new forms of synthesis and combination of this inextricable human-non-human relationship $[57,58]$. In the case of recyclable solid waste, it is necessary to consider the material world, the abilities of management, and the capacity of institutions, civil society, and organizational structures to act independently and interdependently with human actors [55].

Many things are active parts in the construction of the social world $[59,60]$, with equal status within the network [51]. However, recycling can change the materiality of waste by generating different configurations of technical knowledge, moral codes, and the problematization of life. The effect of animating waste is revealed, making it capable of making claims and capturing humans-as long as they are receptive-into new networks of obligation and responsibilities [58].

According to ANT, the collective construction of facts can be understood through a process of translation: "To translate is to displace ( . . . ) is also to express in one's own language what others say and want, why they act in the way they do and how they associate with each other: it is to establish oneself as a spokesman" [53] (p. 223). The results of a network are achieved by translating the various actors into a common goal, called the obligatory point of passage (OPP).

In this sense, it is possible to understand the narratives presented as the process of translation, in which human and non-human entities acted in the construction and deconstruction of a network that supported the waste picker cooperative.

In this case, the process of translation is composed of four phases: problematization, interessement, registration, and mobilization. During these phases, which may overlap, "the identity of actors, the possibility of interaction, and the margins of maneuvres are negotiated and delimited" [53] (p. 203).

In the problematization phase, a specific actor observes a problem, identifies a set of humans and non-humans that can help in the construction of potential solutions, and defines their identities based on a system of alliances or associations. In this context, the actor becomes indispensable to the emerging network [53]. The starting point of this investigation is the employees of the Sustainable Development Commission (CADS), linked to the Secretariat of Social Development of the Municipality of Porto Feliz. These constituted the first engines of history and, according to Callon, at this stage of the investigation, it does not matter where they came from and the reasons that made them act [53].

In the network under analysis, bureaucrats established the construction of a waste picker cooperative as an obligatory point of passage and identified new actors directly involved in the narrative. The actants are the self-employed waste pickers who worked in 
the municipality, the generators of recyclable materials, the recyclable material to be sorted and sold, the headquarters for the cooperative, and the trucks to carry out the collection of materials.

However, problematization, which is a hypothetical aspect, indicates the need for movements that need to be accepted and alliances that must be built, defining the actors' identities and what they want from the network. Each actant listed in the problematization phase may or may not agree with the initial proposition [53], which leads to the second moment of the translation process: interessement.

Interessement is a term proposed by Callon, chosen due to the etymology of "interest" and means being between (inter-be). Interessement represents the set of actions by which the first actor who identified the problem strives to attract the attention of actants identified during the problematization phase. In the case under analysis, actants identified by CADS bureaucrats were previously involved in the problematization of other actors, and it is in this sense that interessement must be understood. "To interest ( . . ) is to build devices which can be placed between them and all other entities who want to define their identities otherwise" [53] (p. 208). In this process, the actor witnesses the redefinition of his identity, goals, and inclinations within the network through the construction of connections with other actors in the same network.

Among the actants identified for the composition of the waste recycling network of Porto Feliz, the self-employed waste pickers deserve to be highlighted. In explanatory meetings, CADS bureaucrats tried to convince pickers that their interests also converged with the existence of a cooperative in the municipality. However, these efforts were not enough to interest them due to the fear of income reduction, since they already obtained sufficient resources for their survival through isolated action and refused to join the network under construction. The interessement was not enough to disassociate them from the network in which they already acted in isolation as pickers, sorters, and resellers of recyclable materials.

For the composition of the network in the role of pickers and sorters of recyclable material, the solution was to look for people assisted by the Secretariat of Social Development, recognized as socially vulnerable. During the initial meetings with these actors, some became convinced that their interests coincided with those of the emerging network: to create a cooperative of recyclable material pickers in Porto Feliz.

Despite the good results obtained by the enrolment of individuals in vulnerable situations in the network, the creation of the cooperative and the non-formalization of pickers who already worked in the municipality reinforced a social cleavage: on the one hand, those who were recognized and assisted by the municipal government and, on the other, the untranslatable, in this case, informal waste pickers.

It is worth noting that interessement does not lead to the construction of alliances; however, when successful, it carries out the inscription. The moment of translation is composed of a set of multilateral negotiations, strength tests, and other devices that determine and test the actors' identities. Finally, it comes to the moment of mobilization, a term chosen to emphasize all the necessary displacements, "to mobilize ( . . ) is to render entities mobile which were not so beforehand" [53] (p. 216).

In the second month of operation, the cooperative members realized that to improve working conditions, it was necessary to expand the network, which would require the enrolment of more human and non-human actors. In this sense, the number of citizens registered for the collection of recyclables was increased, as well as partnerships with companies that started to dispose of recyclables in the cooperative. These aspects enabled the purchase of machinery and equipment, such as conveyors and presses.

The Sociology of Translation also allows for the consideration of the discursive and ideological dimensions of conflicts [55]. As human and non-human actors are mobilized in the network, there is the possibility of "dissidence" or "betrayal". The consensus that mobilizes actants is always temporary, precarious, and open to contestation; "from translation to betrayal there is only a short step" [53] (p. 224). Human and non-human 
actors can depart from the initial objective and redefine their identities, interests, and objectives. As a result, their actions can promote the rearticulation of the network, resulting in a different result, often opposite to the desired result $[34,53]$.

The referred theoretical framework contributes to the understanding of how the nature of a technological solution for waste management changes in relation to changing interactive contexts [55]. In Porto Feliz, management changes in 2013 and 2017 were decisive for the dissidence and replacement of some actors and, as a result, the network progressively lost its strength. The main changes observed were the removal of the intern figure, who technically contributed to the work of the waste pickers, the acquisition of the truck, which triggered conflict between the municipal government and cooperative members, the replacement of the headquarters, and the storm that destroyed part of the new cooperative structure.

After these events, an important actor who was in line with the network's objectives emerged: the businessman, who covered expenses related to the renovation of the cooperative's new headquarters. However, this was not sufficient for the network to attract more members. Perhaps, due to the fact that the actions taken were not enough to interest and enroll the responsibility for waste management in Porto Feliz, waste management continued to be a technical issue, which overlaps management attributes that do not gain evidence.

Translating solid waste from a technical issue into a matter of public interest is fundamental in stabilizing a new waste management system [61]. In Porto Feliz, the emerging network was destabilized by the habits of the original network of the management system and by unexpected events, favoring the maintenance of the municipal solid waste management status quo.

The municipal public power stopped being responsible for promoting sorted waste collection; it only assumed responsibility for undifferentiated collection and final disposal. With this omission, the Federal Law 12,305 of 2010 was ignored, which explicitly attributes the competence of integrated solid waste management to municipalities and requires the incorporation of waste pickers in municipal selective collection programs [62].

The concept "acting at distance" can be used to explain non-compliance with Federal Law. This ANT analytical tool refers to the ability of an "external" actor to enroll a "local" actor in a control network in a region far from the translation center through the mobilization of many intertwined actors [51,63]. In the case under analysis, the Federal Law was not able to extend its networks and reach the socio-technical network of waste management in Porto Feliz. According to the theory, long-distance control depends on a network that makes it possible for an objective to go from the "center" to the "periphery" in a durable, vigorous, and faithful way; it also suggests that, for the success of long-distance control, documents, devices, and trained individuals must act together or separately [63].

\section{Conclusions}

This paper contributes to research in the fields of science, technology, and society and to studies on conflicts in the implementation of a recyclable material picker cooperative. In this article, all variations that affected the sustained alliances around the cooperative are presented, without linking actants to immutable roles throughout the narrative. The theory that explained collected data and the relationships that structured the network became visible and admissible only after the event, meeting the principles of the grounded theory and Sociology of Translation.

Using a case study discussed in the light of the Sociology of Translation, the conflict in the implementation of a waste picker cooperative was presented as the history of a heterogeneous network composed of actants linked by fragile associations. The Sociology of Translation and its theoretical contribution are adequate to describe society and nature, which are associated with stable networks only in a certain place, for a certain time, in continuous displacements and transformations of goals, interests, and non-human and human devices. 
The theory's conceptual repertoire allowed us to understand the role played by human and non-human actors in changing the course of action: the non-stabilized sociotechnical assemblage of the waste picker cooperative, which was not accepted as an uncontroversial solution for the management of recyclable waste in the municipality.

Due to the omission of the Municipal Government, the former cooperative members were relegated to informality, adding to the untranslatable autonomous collectors, who never stopped working in the municipality, which allows us to come to a conclusion about the misalignment of interests between Federal and Municipal Governments.

The results obtained here do not allow for a generic prescription of how to achieve sustainable development through the role of multiple actors. The construction process of heterogeneous networks is dynamic and unpredictable.

In the case of collectors, this path becomes even more intertwined. These individuals are not considered to be an active part of the decision-making process and suffer stigma for sharing the sign of the material they work with. Furthermore, public management is permeated by the alternation of power and the fragmentation of actions planned in the medium and long term.

Once the Federal Public Authority establishes that cooperatives should be the solution adopted by the municipalities for the management of recyclables, the next steps of the research are to track explanations for the fact that the Federal Law is not able to extend its networks and reach the socio-technical waste management network of Porto Feliz. This search will be carried out through the planning instruments established by the Federal Law (actants) since no idea (or objective) circulates without concrete material means.

Finally, since social structure is a process, no version of the social order is final. In this way, by changing the structure of networks (convoking new and more suitable actants), it is possible to move towards the inclusion of collectors. By shedding light on negotiations and conflicts that permeated the implementation of the Porto Feliz Recyclable Material Collectors Cooperative, this article hopes to have contributed to achieving the sustainable development of this and other urban areas.

Author Contributions: Conceptualization, P.S.d.C.R. and S.R.; methodology, P.S.d.C.R. and S.R.; validation, P.S.d.C.R. and S.R.; formal analysis, P.S.d.C.R.; investigation, P.S.d.C.R.; resources, P.S.d.C.R. and S.R.; data curation, P.S.d.C.R. and S.R.; writing-original draft preparation, P.S.d.C.R.; writingreview and editing, P.S.d.C.R., E.W.R. and S.R.; visualization, E.W.R. and S.R.; supervision, E.W.R. and S.R.; project administration, P.S.d.C.R. and S.R. All authors have read and agreed to the published version of the manuscript.

Funding: This research received no external funding.

Institutional Review Board Statement: The study was conducted according to the guidelines of the Declaration of Helsinki, and approved by the Institutional Review Board of Federal University of Minas Gerais (protocol code: 23082819.9.0000.5149 and date of approval: 7 November 2019).

Informed Consent Statement: Informed consent was obtained from all subjects involved in the study.

Data Availability Statement: Not applicable.

Conflicts of Interest: The authors declare no conflict of interest.

\section{References}

1. Adedipe, N.O.; Sridhar, M.K.C.; Baker, J.; Verma, M. Waste Management, Processing, and Detoxification. In Ecosystems and Human Well-Being: Policy Responses: Findings of the Responses Working Group; Island Press: Washington, DC, USA, 2005 ; pp. 313-334.

2. Noel, C. Solid waste workers and livelihood strategies in Greater Port-au-Prince, Haiti. Waste Manag. 2010, 30, 1138-1148. [CrossRef] [PubMed]

3. Hettiarachchi, H.; Ryu, S.; Caucci, S.; Silva, R. Municipal Solid Waste Management in Latin America and the Caribbean: Issues and Potential Solutions from the Governance Perspective. Recycling 2018, 3, 19. [CrossRef]

4. Tong, Y.D.; Huynh, T.D.X.; Khong, T.D. Understanding the role of informal sector for sustainable development of municipal solid waste management system: A case study in Vietnam. Waste Manag. 2021, 124, 118-127. [CrossRef] [PubMed]

5. Dias, S.M. Waste pickers and cities. Environ. Urban. 2016, 28, 375-390. [CrossRef] 
6. Severi, F.C. Os catadores de materiais recicláveis e reutilizáveis na Política Nacional de Resíduos Sólidos. Rev Direito E Práxis. 2014, 5, 152-171.

7. Wilson, D.; Velis, C.; Cheeseman, C. Role of informal sector recycling in waste management in developing countries. Habitat Int. 2006, 30, 797-808. [CrossRef]

8. Gunsilius, E. Recovering Resources, Creating Opportunities. Integrating the Informal Sector into Solid Waste Managment. Deutsche Gesellschaft für ... . Deutsche Gesellschaft für Internationale Zusammenarbeit (GIZ). 2011. Available online: http:/ / scholar.google.com/scholar?hl=en\&btnG=Search\&q=intitle:Recovering+resources+Creating+opportunities . +Integrating+the+informal+sector+into+Solid+Waste+Managment\#0\%5Cnhttp://scholar.google.com/scholar?hl=en\&btnG= Search\&q=intitle:Recovering+Resources+C (accessed on 3 November 2017).

9. Pinhel, J.R. Do Lixo à Cidadania. Guia Para a Formação de Cooperativas de Catadores de Materiais Recicláveis; Editora Peirópolis: São Paulo, Brazil, 2013; 239p.

10. Campos, H.K.T. Recycling in Brazil: Challenges and prospects. Resour. Conserv. Recycl. 2014, 85, 130-138. [CrossRef]

11. Medina, M. Scavenger cooperatives in Asia and Latin America. Resour. Conserv. Recycl. 2000, 31, 51-69. [CrossRef]

12. Medina, F. Consideraciones Sobre el Índice de Gini para Medir la Concentración del Ingresso. Santiago de Chile; (Estudios estadísticos y prospectivos). Report No.: 9. 2001. Available online: https://repositorio.cepal.org/bitstream/handle/11362/4788 /S01020119_es.pdf?sequence=1\&isAllowed=y (accessed on 3 November 2017).

13. Gutberlet, J. Informal and Cooperative Recycling as a Poverty Eradication Strategy. Geogr. Compass 2012, 6, 19-34. [CrossRef]

14. Gutberlet, J. Gestão inclusiva de resíduos sólidos. Rev. Geogr. 2013, 30, 6-23.

15. Pongrácz, E.; Pohjola, V.J. Re-defining waste, the concept of ownership and the role of waste management. Resour. Conserv. Recycl. 2004, 40, 141-153. [CrossRef]

16. Gutberlet, J.; de Jayme, B.O. A história do meu rosto: Como agentes ambientais percebem a estigmatização (re)produzida pelo discurso. Geogr. Questão. 2012, 5, 183-200.

17. Teodósio, A.S.S.; Dias, S.F.L.G.; Santos, M.C.L. Procrastinação da Política Nacional de Resíduos Sólidos: Catadores, governos e empresas na governança urbana. Cienc. Cult. 2016, 68, 30-35. [CrossRef]

18. Fidelis, R.; Marco-Ferreira, A.; Antunes, L.C.; Komatsu, A.K. Socio-productive inclusion of scavengers in municipal solid waste management in Brazil: Practices, paradigms and future prospects. Resour. Conserv. Recycl. 2019, 154, 104594. [CrossRef]

19. Paul, J.G.; Arce-Jaque, J.; Ravena, N.; Villamor, S.P. Integration of the informal sector into municipal solid waste management in the Philippines-What does it need? Waste Manag. 2012, 32, 2018-2028. [CrossRef]

20. Pereira da Silva, T.M. A Materially Contextualised Account of Waste Pickers' Marginalisation in Brazil: The Case of 'Rubbish PET'. Worldw. Waste J. Interdiscip. Study 2019, 13, 2. [CrossRef]

21. Glaser, B.G.; Strauss, A.L. The Discovery of Grounded Theory: Strategies for Qualitative Research; Aldine Publishing: Chicago, IL, USA, 1967.

22. Reichertz, J. Abduction: The logic of Discovery of Grounded Theory. In The Sage Handbook of Grounded Theory; Sage: London, UK, 2007; pp. 214-228.

23. Bandeira-de-Mello, R.; de Cunha, C.J.C.A. Grounded theory. In GODOI, Christiane Kleinübing; BANDEIRA-DE-MELLO, Rodrigo; SILVA, Anielson Barbosa Da Pesquisa Qualitativa em Estudo em Estudos Organizacionais: Paradigmas, Estratégias e Métodos; Saraiva: São Paulo, Brazil, 2006; pp. 241-266.

24. Dantas, C.D.C.; Leite, J.L.; de Lima, S.B.S.; Stipp, M.A.C. Teoria fundamentada nos dados-Aspectos conceituais e operacionais: Metodologia possível de ser aplicada na pesquisa em enfermagem. Latino-am Enferm. 2009, 17, 573-579. [CrossRef]

25. Morse, J.M. Sampling in Grounded Theory. In The Sage Handbook of Grounded Theory; Sage: London, UK, 2007 ; pp. $229-244$.

26. Nico, L.S.; Bocchi, S.C.M.; Ruiz, T.; Moreira, R.D.S. A Grounded Theory como abordagem metodológica para pesquisas qualitativas em odontologia. Ciência Saúde Coletiva 2007, 12, 789-797. [CrossRef] [PubMed]

27. Tarozzi, M. O que é a Grounded Theory: Metodologia de Pesquisa e de Teoria Fundamentada nos Dados; Vozes: Petrópolis, Brazil, 2011; $189 \mathrm{p}$.

28. Pinto, M.d.R.; Santos, L.L.d.S. A grounded theory como abordagem metodológica: Relatos de uma experiência de campo. Organ Soc. 2012, 19, 417-436. [CrossRef]

29. Strauss, A.; Corbin, J. Bases de la Investigación Cualitativa: Técnicas y Procedimientos para Desarrollar La Teoria Fundamentada, 2nd ed.; Editorial Universidad de Antioquia: Medellín, Colombia, 2002; 340p.

30. Seade, Fundação Sistema Estadual de Análise de Dados. Repositório de Dados. 2021. Available online: https://painel.seade.gov. br/repositorio-de-dados / (accessed on 3 November 2021).

31. PNUD P das NU para o, D. Atlas do Desenvolvimento Humano no Brasil. 2011. Available online: http://www.atlasbrasil.org.br/ perfil/municipio/354060 (accessed on 24 January 2021).

32. Instituto Brasileiro de Geografia e Estatística (IBGE). Available online: https:/ / cidades.ibge.gov.br/ (accessed on 15 November 2020).

33. Czarniawska, B. Narratives in Social Science Research; Sage: London, UK, 2004.

34. Guzman, G.; De Souza, M.M.P. Shifting modes of governing municipal waste-A sociology of translation approach. Environ. Plan A 2018, 50, 922-938. [CrossRef]

35. Revista Viu! Evento Será dia 17 de Outubro. 2008. Available online: http://www.revistaviu.com.br/noticias/evento-sera-dia-17 -de-outubro/20081014163440_M_035 (accessed on 17 July 2020). 
36. Revista Viu! Maffei Vence Eleição com 18.262 dos Votos Válidos. 2008. Available online: http:/ / www.revistaviu.com.br/noticias / maffei-vence-eleicao-com-18-262-dos-votos-validos/20081016115148_W_022 (accessed on 17 July 2020).

37. Easycoop Cooperativismo em Revista. Cidade de Porto Feliz Cria sua Primeira Cooperativa de Reciclagem. 2010. Available online: http:/ / easycoop.com.br/Noticias/View.aspx?id=11143 (accessed on 18 July 2020).

38. Cooperativa Monções de Coleta Seletiva; Estatuto Social: Porto Feliz, Brazil, 2010. Available online: http:https://silo.tips/download/ cooperativa-monoes-de-coleta-seletiva-de-porto-feliz-rua-anita-garibaldi-n694-jd (accessed on 18 December 2019).

39. Cooperativa de Porto Feliz Recebe Prensa de Materiais Reciclados. 2010. Available online: https://www.itu.com.br/regiao/ noticia/cooperativa-de-porto-feliz-recebe-prensa-de-materiais-reciclados-20100416 (accessed on 26 July 2020).

40. Projeto para Coleta de Recicláveis tem Início em Porto Feliz. 2010. Available online: https://www.itu.com.br/regiao/noticia/ projeto-para-coleta-de-reciclaveis-tem-inicio-em-porto-feliz-20100304 (accessed on 26 July 2020).

41. Revista Viu! Cerca de 100 Toneladas Foram Recolhidas Desde a Implantação. 2011. Available online: http:/ / www.revistaviu.com. br/noticias/cerca-de-100-toneladas-foram-recolhidas-desde-a-implantacao/20110204093844_D_092 (accessed on 26 July 2020).

42. Cooperativa de Reciclagem de Porto Feliz Pretende Expandir Coleta. 2011. Available online: https://www.itu.com.br/regiao/ noticia/cooperativa-de-reciclagem-de-porto-feliz-pretende-expandir-a-coleta-20110426 (accessed on 26 July 2020).

43. G1 Sorocaba e Jundiaí. Porto Feliz, SP, faz Recolhimento Óleo Usado e Gera Renda Para Cooperados. 2012. Available online: http:/ /g1.globo.com/sao-paulo/sorocaba-jundiai/noticia/2012/02/ porto-feliz-sp-faz-recolhimento-oleo-usado-e-gerarenda-para-cooperados.html (accessed on 26 July 2020).

44. Revista Viu! Cooperativa de Coleta Seletiva Monções de Porto Feliz Inicia Projeto "Recicla Porto". 2013. Available online: http:/ / www.revistaviu.com.br/noticias / cooperativa-de-coleta-seletiva-moncoes-de-porto-feliz-inicia-projeto-recicla-porto / 20131001132427_P_194 (accessed on 26 July 2020).

45. G1 Sorocaba e Jundiaí. Tempestade faz Estragos e Provoca Mortes em Porto Feliz, SP. 2013. Available online: http://g1.globo.com/ sao-paulo/sorocaba-jundiai/noticia/2013/07/tempestade-faz-estragos-e-provoca-mortes-em-porto-feliz-sp.html (accessed on 26 July 2020).

46. Revista Viu! Cooperativa de Reciclagem Monções Inaugura novo Barracão. 2013. Available online: http:/ / www.revistaviu.com. br/noticias / cooperativa-de-reciclagem-moncoes-inaugura-novo-barracao/20130718150923_N_481 (accessed on 27 July 2020).

47. Prefeitura do Município de Porto Feliz. Lei no 5.226 de 10 de Dezembro de 2013. Declara de Utilidade Pública a Cooperativa de Coleta Seletiva Monções de Porto Feliz, Conforme Especifica, e dá Outras Providências. Brasil. 2013. Available online: https:/ /leismunicipais.com.br/a1/sp/p/porto-feliz/lei-ordinaria/2019/570/5698/lei-ordinaria-n-5698-2019-declara-deutilidade-publica-a-cooperativa-de-trabalho-de-coleta-seletiva-porto-das-moncoes-de-porto-feliz-conforme-especifica-e-daoutras-providencias (accessed on 18 December 2019).

48. Canal, I.T.V. Coleta Seletiva Será Retomada a Partir de Segunda-Feira em Porto Feliz. 2017. Available online: www.canalitv.com. $\mathrm{br} /$ noticia/853/coleta-seletiva-sera-retomada-a-partir-de-segunda-feira-em-porto-feliz.html (accessed on 18 December 2019).

49. Haig, B.D. Grounded theory as scientific method. Philos Educ. 1995, 1, 1-11.

50. Latour, B. Ciência em Ação: Como Seguir Cientistas e Engenheiros Sociedade Afora; Editora UNESP: São Paulo, Brazil, 2012.

51. Bowler, I.R. Recycling urban waste on farmland: An actor-network interpretation. Appl. Geogr. 1999, 19, 29-43. [CrossRef]

52. Latour, B. The powers of association. Sociol. Rev. 1984, 32, 264-280. [CrossRef]

53. Callon, M. Some Elements of a Sociology of Translation: Domestication of the Scallops and the Fishermen of St Brieuc Bay. Sociol. Rev. 1984, 32, 196-233. [CrossRef]

54. Khoo, S.-M.; Rau, H. Movements, mobilities and the politics of hazardous waste. Environ. Politics 2009, 18, 960-980. [CrossRef]

55. Magnani, N. Nonhuman Actors, Hybrid Networks, and Conflicts Over Municipal Waste Incinerators. Organ. Environ. 2012, 25, 131-145. [CrossRef]

56. Latour, B. Jamais Fomos Modernos; Editora: Rio de Janeiro, Brazil, 1994; 152p.

57. Murdoch, J. Ecologising Sociology: Actor-Network Theory, Co-Construction and the Problem of Human Exemptionalism. Sociology 2001, 35, 111-133. [CrossRef]

58. Hawkins, G. The politics of bottled water. J. Cult. Econ. 2009, 2, 183-195. [CrossRef]

59. Latour, B. On Actor-Network Theory: A Few Clarifications. Soz. Welt. 1996, 47, 369-381.

60. Latour, B. Reagregando o Social: Uma Introdução à Teoria do Ator-Rede; Edufba-Edusc: Salvador-Bauru, Brazil, 2012.

61. Hird, M.J.; Lougheed, S.; Rowe, R.K.; Kuyvenhoven, C. Making waste management public (or falling back to sleep). Soc. Stud. Sci. 2014, 44, 441-465. [CrossRef]

62. Brasil. Lei n. 12.305, de 2 de agosto de 2010. Institui a Política Nacional de Resíduos Sólidos; Altera a Lei n. 9.605 , de 12 de Fevereiro de 1998, e dá Outras Providências. Brasil; 2010; p. 21. Available online: http://www.planalto.gov.br/ccivil_03/_ato200 7-2010/2010/lei/112305.htm (accessed on 5 January 2017).

63. Law, J. On the methods of long-distance control: Vessels, navigation and the Portuguese route to India. In Power, Action and Belief: A New Sociology of Knowledge? Routledge: London, UK, 1986; pp. 234-263. 